REGULAR ARTICLE

\title{
PRODUCTION OF INDUSTRIALLY IMPORTANT ENZYMES BY THERMOBACILLI ISOLATED FROM HOT SPRINGS OF INDIA
}

\section{ASHISH DHYANI ${ }^{1}$, RITU GURURANI ${ }^{2}$, SAMY A. SELIM ${ }^{1,3,4}$, PRIYANKA ADHIKARI ${ }^{1}$, AVINASH SHARMA5, VEENA PANDE ${ }^{2}$, ANITA PANDEY ${ }^{*}$}

\author{
${ }^{1}$ Biotechnological Applications, G. B. Pant National Institute of Himalayan Environment and Sustainable Development, Kosi- \\ Katarmal, Almora 263643, Uttarakhand, India
}

${ }^{2}$ Department of Biotechnology, Kumaun University, Bhimtal 263136, Uttarakhand, India

3Department of Clinical Laboratory Sciences, College of Applied Medical Science, Jouf University, Sakaka- 2014, Saudi Arabia

4Microbiology and Botany Department, Faculty of Sciences, Suez Canal University, Ismailia-41522, Egypt

5Microbial Culture Collection, National Center for Cell Sciences, Ganeshkhind, Pune 411007, Maharashtra, India

\begin{abstract}
Enzymes from thermophilic bacteria have received great attention for their potential applications in various industrial sectors. The present study deals with the production of five thermozymes (amylase, lipase, xylanase, protease and cellulase) from 10 thermophilic bacterial species, originally isolated from two hot springs namely Soldhar and Ringigad in Uttarakhand Himalaya, India. The bacterial isolate GBPI_25 produced maximum amylase $(1217.86 \mathrm{U} / \mathrm{ml})$ at $45{ }^{\circ} \mathrm{C}$ and $5 \mathrm{pH}$, GBPI 3 produced maximum lipase $(22.59 \mathrm{U} / \mathrm{ml})$ at $65{ }^{\circ} \mathrm{C}$ and $9 \mathrm{pH}$, GBPI_25 produced maximum xylanase $(98.07 \mathrm{U} / \mathrm{ml})$ at $45{ }^{\circ} \mathrm{C}$ and $9 \mathrm{pH}$, GBPI_35 produced maximum protease $(16.66 \mathrm{U} / \mathrm{ml})$ at $55^{\circ} \mathrm{C}$ and $9 \mathrm{pH}$, and GBPI 4 produced maximum cellulose (108.68 $\mathrm{U} / \mathrm{ml}$ ) at $45{ }^{\circ} \mathrm{C}$ and $5 \mathrm{pH}$. Crude enzyme preparations showed thermal and $\mathrm{pH}$ activities at broad temperature and $\mathrm{pH}$ range between $10-100{ }^{\circ} \mathrm{C}$ and $3-11 \mathrm{pH}$, respectively, with different temperature and $\mathrm{pH}$ optima. Amylase, xylanase and cellulase showed maximum activity at $50{ }^{\circ} \mathrm{C}$ while lipase and protease showed higher activity at 40 and $60{ }^{\circ} \mathrm{C}$, respectively. Enzyme activity at wide temperature range-cellulase and protease from $10-100{ }^{\circ} \mathrm{C}$, amylase and xylanasefrom $10-90{ }^{\circ} \mathrm{C}$, and lipase activity from $10-80{ }^{\circ} \mathrm{C}$ were the remarkable records from this study. Similarly, pH range for amylase and lipase activity was recorded from 4-11, for xylanase from 3-9, and for protease and cellulase from 3-10. All the thermozymes showed maximum stability at $40^{\circ} \mathrm{C}$ and $\mathrm{pH} 5$ except cellulase that showed higher stability at $40{ }^{\circ} \mathrm{C}$ and neutral $\mathrm{pH}$.
\end{abstract}

Keywords: Hot springs, Thermobacilli, Thermozymes, Enzyme activity, Enzyme stability

\section{INTRODUCTION}

Enzymes are biological catalysts that involve in numerous metabolic and biochemical reactions. They are widely applicable in biotechnological industries such as paper, pulp, food, textile, beverage, pharmaceutical and cosmetics. The demand of industrial enzymes has been projected to be US $\$ 7,100$ million in 2018 with a yearly increase at $8 \%$ progression [1]. Enzymes from microorganisms have several advantages like lower cost, higher product recovery, ease for genetic manipulation, regular availability and rapid in growth over plant and animal derived enzymes. Out of nearly 4000 known enzymes, about 200 microbial enzymes are applicable at commercial levelwhile2o enzymes are produced at industrial scale [2]. Enzymes from the microbial sources are known for better-quality and extracted from a range of microorganisms including bacteria, actinobacteria and fungi and used for commercial applications [3].

Extremophilic microorganisms are capable for the production of extremozymes which have unusual properties like salt allocation, thermostability and adaptability [4]. These enzymes are responsible for the survival of extremophiles in stressed environmental conditions and also support various biotechnological applications. Extremozymes like amylase, lipase, xylanase, cellulase and protease have wide applications in many biotechnological processes. These enzymes have been used since many years in paper, pulp, food and pharmaceutical industries [5].

Received 11 October 2017; Accepted 30 December 2017

*Corresponding Author

Anita Pandey

Biotechnological Applications, G. B. Pant National Institute of Himalayan Environment and Sustainable Development, KosiKatarmal, Almora 263643, Uttarakhand, India

Email: anita@gbpihed.nic.in

( This article is open access and licensed under the terms of the Creative Commons Attribution License (http://creativecommons.org/licenses/by/4.o/) which permits unrestricted, use, distribution and reproduction in any medium, or format for any purpose, even commercially provided the work is properly cited. Attribution - You must give appropriate credit, provide a link to the license, and indicate if changes were made. 
Indian Himalayan region (IHR), due to its different topographic, geographic and climatic conditions, is increasingly getting attention for its so far untapped microbial diversity. Hot springs, namely Soldhar and Ringigad located in Chamoli district of Uttarakhand state in IHR, have been a focus for understanding the basic and applied aspects of the microbial diversity of thermophiles. These thermophilic organisms are important in view of their bioprospecting including their diversity, applications and conservation [6-11].

Several environmental factors influence the production of large amount of enzymes. Media composition, temperature and $\mathrm{pH}$ are among the important factors that have pivotal impact on economy and viability of the production of enzymes, therefore, standardization of these factors is important [12]. In this background, the present study deals with 10 selected thermophilic bacteria (species of Bacillus, Geobacillus and Paenibacillus) with particular reference to the production of 5 industrially important enzymes along with the activity and stability at different physiological conditions i.e. temperature, $\mathrm{pH}$ and incubation time.

\section{MATERIALS AND METHODS}

\section{Bacterial isolates and characterization Qualitative screening}

10 thermophilic bacteria (species of Bacillus, Geobacillus and Paenibacillus), originally isolated from the sediments of two hot springs namely Soldhar and Ringigad, were taken from the Microbial Culture Collection established in Microbiology Lab of the Institute (GBPNIHESD). The bacterial cultures were identified on the basis of their phenotypic and genotypic characters as GBPI 3-Geobacillus stearothermophilus; GBPI 4-G. kaustophilus; GBPI13-G. stearothermophilus; GBPI_16$G$. stearothermophilus; GBPI_22-Bacillus licheniformis; GBPI_25-B. tequilensis; GBPI_30-Paenibacillus ehimensis; GBPI_31-P. ehimensis; GBPI_35-B. licheniformis; GBPI_37$B$. sonorensis [10,13-15]. General description of these thermophilic bacteria are presented in table 1 .

The bacterial species were examined for the production of 5 extracellular enzymes namely amylase, lipase, xylanase, protease and cellulase. In brief, point inoculation of bacterial species was done on respective agar medium and incubated for $24 \mathrm{~h}$ at $55{ }^{\circ} \mathrm{C}$. After incubation, starch, carboxymethyl cellulose (CMC) and xylanase producing agar plate was flooded with Gram's iodine for observing zone of clearance around the bacterial colony. Zone of clearance for lipolytic and proteolytic activity was recorded on tributyrin agar and skim milk agar, respectively.

Table 1: Colony morphology and microscopic characters of thermobacilli

\begin{tabular}{|c|c|c|c|c|c|}
\hline \multirow{2}{*}{$\begin{array}{l}\text { S. } \\
\text { No. }\end{array}$} & \multirow{2}{*}{$\begin{array}{l}\text { Isolate } \\
\text { code }\end{array}$} & \multicolumn{2}{|l|}{ Phenotypic characters } & \multirow[t]{2}{*}{ Bacterial species } & \multirow{2}{*}{$\begin{array}{l}\text { Nucleotide } \\
\text { accession no. }\end{array}$} \\
\hline & & Colony morphology & Cell morphology & & \\
\hline 1 & GBPI 3 & $\begin{array}{l}\text { Light yellow, smooth, slimy, } \\
\text { circular, convex, o.3-1.0 mm } \\
\text { dia }\end{array}$ & $\begin{array}{l}\text { o.6-0.8 } \times 3.2-4.5 \mu \mathrm{m} \text {, rod } \\
\text { shaped, single, diplobacilli, } \\
\text { short or long spiral chains }\end{array}$ & $\begin{array}{l}\text { Geobacillus } \\
\text { stearothermophilus }\end{array}$ & EU381182 \\
\hline 2 & GBPI 4 & $\begin{array}{l}\text { Light yellow, smooth, slimy, } \\
\text { circular, convex, 7.5-9.0 mm } \\
\text { dia }\end{array}$ & $\begin{array}{l}\text { o.8-1.0 } \times 6.0-8.0 \mu \mathrm{m} \text {, rod } \\
\text { shaped, single, diplobacilli, } \\
\text { short or long spiral chains }\end{array}$ & G. kustophilus & EU381189 \\
\hline 3 & GBPI 13 & $\begin{array}{l}\text { Light yellow, smooth, slimy, } \\
\text { circular, convex, 3-6 mm dia }\end{array}$ & $\begin{array}{l}\text { o.6-0.8 } \times 4.5-5.0 \mu \mathrm{m} \text {, rod } \\
\text { shaped, single, diplobacilli or } \\
\text { short chains }\end{array}$ & $\begin{array}{l}\text { G. } \\
\text { stearothermophilus }\end{array}$ & EU381187 \\
\hline 4 & GBPI_16 & $\begin{array}{l}\text { Yellowish cream, smooth, } \\
\text { slimy, circular, convex, o.7-1.o } \\
\text { mm dia }\end{array}$ & $\begin{array}{l}\text { o.8-1.0 } \times 6.0-8.0 \mu \mathrm{m}, \text { rod } \\
\text { shaped, scattered or in } \\
\text { clusters or short to long } \\
\text { chains }\end{array}$ & $\begin{array}{l}\text { G. } \\
\text { stearothermophilus }\end{array}$ & FJ548759 \\
\hline 5 & GBPI_22 & $\begin{array}{l}\text { Creamish-white, smooth, } \\
\text { convex and round colony, 2.o- } \\
10 \mathrm{~mm} \text { dia }\end{array}$ & $\begin{array}{l}0.6-0.9 \times 5.0-5.6 \mu \mathrm{m} \text {, rods in } \\
\text { long chains }\end{array}$ & $\begin{array}{l}\text { Bacillus } \\
\text { licheniformis }\end{array}$ & KF862007 \\
\hline 6 & GBPI_25 & $\begin{array}{l}\text { Creamish-white, smooth, } \\
\text { convex and round colony, 1.o- } \\
2.0 \mathrm{~mm} \text { dia }\end{array}$ & $\begin{array}{l}\text { 0.8-1.0 } \times 7.0-7.5 \mu \mathrm{m} \text {, rods in } \\
\text { long chains }\end{array}$ & $\begin{array}{l}\text { Paenibacillus } \\
\text { ehimensis }\end{array}$ & KF862010 \\
\hline 7 & GBPI_30 & $\begin{array}{l}\text { Off-white, smooth, convex- } \\
\text { round colony, 1.0-2.0 mm dia }\end{array}$ & $\begin{array}{l}\text { o.6-0.8 } 8 \times 5.0-5.5 \mu \mathrm{m} \text {, rods in } \\
\text { long chains }\end{array}$ & P. ehimensis & KF862013 \\
\hline 8 & GBPI_31 & $\begin{array}{l}\text { Creamish-white, irregular, } \\
\text { convex-raised colony, 4.0-5.0 } \\
\text { mm dia }\end{array}$ & $\begin{array}{l}0.5-08 \times 4.0-5.5 \mu \mathrm{m} \text {, rods in } \\
\text { long chains }\end{array}$ & P. ehimensis & KF862013 \\
\hline 9 & GBPI_35 & $\begin{array}{l}\text { Creamish-white, smooth, } \\
\text { convex-round colony, 1.0-1.2 } \\
\text { mm dia }\end{array}$ & $\begin{array}{l}0.6-0.8 \times 4.5-5.0 \mu \mathrm{m} \text {, single } \\
\text { rods }\end{array}$ & P. ehimensis & KF862018 \\
\hline 10 & GBPI_37 & $\begin{array}{l}\text { Creamish-white, smooth, } \\
\text { convex-round colony, 1.0-3.o } \\
\text { mm dia }\end{array}$ & $\begin{array}{l}\text { o.6-0.8 } 6.5 .5-7.0 \mu \mathrm{m} \text {, single } \\
\text { rods }\end{array}$ & B. sonorensis & KF862020 \\
\hline
\end{tabular}




\section{Quantitative production}

The quantitative production of all five thermozymes was carried out under three different temperatures 45, 55 and 65 ${ }^{\circ} \mathrm{C}$; at each temperature enzyme production was recorded at 5,7 and $9 \mathrm{pH}$ up to $72 \mathrm{~h}$ with an interval of $24 \mathrm{~h}$.

\section{Amylase assay}

Amylase production was carried out in $250 \mathrm{ml}$ conical flask containing $100 \mathrm{ml}$ medium with following chemical composition in 1 liter: corn starch $5 \mathrm{~g}$, yeast extract $5 \mathrm{~g}$,

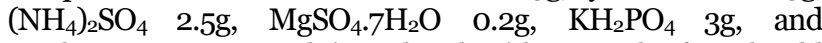
$\mathrm{CaCl}_{2.2} \mathrm{H}_{2} \mathrm{O} 0.25 \mathrm{~g}$ and inoculated with $0.1 \mathrm{ml}$ of $12 \mathrm{~h}$ old culture. The flasks were incubated at different temperatures (45, 55 and $\left.65{ }^{\circ} \mathrm{C}\right)$ and $\mathrm{pH}(5,7$ and 9) for defined incubation time in static conditions. After incubation, biomass and enzyme activity was recorded at an interval of $24 \mathrm{~h}$ up to $72 \mathrm{~h}$. All the experiments were conducted in triplicates.

Amylase activity was measured by using di-nitrosalicylic acid (DNSA) method [16]. The reaction mixture contained $0.3 \mathrm{ml}$ crude enzyme, $0.5 \mathrm{ml}$ different $\mathrm{pH}$ buffer, $0.2 \mathrm{ml}$ of $1 \%(\mathrm{w} / \mathrm{v})$ of corn starch as substrate and incubated at room temperature for $2 \mathrm{~min}$. After incubation, $1 \mathrm{ml}$ of DNSA was added to reaction mixture and kept in boiling water bath for $10 \mathrm{~min}$. After boiling, reaction mixture was allowed to cool at room temperature and change in colour was measured at $540 \mathrm{~nm}$ against substrate blank as well as enzyme blank. Enzyme activity was recorded in terms of the amount of enzyme required to release 1.o $\mu$ g of glucose per min under specified assay conditions.

\section{Lipase assay}

Lipase producing medium contained $\mathrm{NaNO}_{3} 3.0 \mathrm{~g}, \mathrm{~K}_{2} \mathrm{HPO}_{4}$ o.1g, $\mathrm{MgSO}_{4} .7 \mathrm{H}_{2} \mathrm{O} 0.5 \mathrm{~g}, \mathrm{KCl} 0.5 \mathrm{~g}, \mathrm{FeSO}_{4 .} .7 \mathrm{H}_{2} \mathrm{O}$ o.01g, yeast extract5.og and $1 \%$ olive oil in 1 liter and inoculated with 0.1 $\mathrm{ml}$ of $12 \mathrm{~h}$ old culture. Cell biomass and lipase activity was observed at an interval of $24 \mathrm{~h}$ up to $72 \mathrm{~h}$. Lipase activity was determined following Pinsirodom and Parkin [17] method. In brief, reaction mixture was prepared by mixing $1 \mathrm{ml}$ of $4^{-}$ nitrophenyl laurate ( $p$ NPL) as lipase substrate, $1 \mathrm{ml}$ buffer of desired $\mathrm{pH}$ and $0.4 \mathrm{ml}$ crude enzyme extract, incubate reaction mixture at room temperature for $2 \mathrm{~min}$. Thereafter, absorbance was recorded at $410 \mathrm{~nm}$ and amount of enzyme expressed in terms of enzyme unit which was defined as the $\mu \mathrm{mol}$ of $p \mathrm{NP}$ released per minute.

\section{Xylanase assay}

Xylanase production by thermophilic bacterial isolates was recorded by incubating bacterial cells in xylanase producing broth medium having composition in liter as follows: yeast extract 10 , glucose $10 \mathrm{~g}$, tween $801 \mathrm{ml}$, brich wood xylan1og, $100 \mathrm{ml}$ of medium was distributed in $250 \mathrm{ml}$ conical flask. The medium was inoculated with $0.1 \mathrm{ml}$ of $12 \mathrm{~h}$ old culture and incubated at different temperature and $\mathrm{pH}$ under static conditions for desired time period. After incubation period, broth medium was centrifuged at 10,000 rpm for $15 \mathrm{~min}$ and cell free supernatant was used as source of enzyme.

Xylanase activity was measured by using $1 \%$ xylan in desired $\mathrm{pH}$ buffer as substrate described by Bailey et al. [18] and quantity of reducing sugar released by the hydrolysis of xylan was observed by Miller [16]. In brief, reaction mixture contained $0.9 \mathrm{ml}$ xylan solution and $0.1 \mathrm{ml}$ crude extract; it was incubated for $2 \mathrm{~min}$ at room temperature. Following incubation, $1.5 \mathrm{ml}$ of DNSA was added to reaction mixture and kept at $50{ }^{\circ} \mathrm{C}$ for $15 \mathrm{~min}$. After boiling, reaction mixture was allowed to cool at room temperature and change in colour was measured at $540 \mathrm{~nm}$. One unit of xylanase activity was defined as the amount of enzyme that required for the release of $1 \mu \mathrm{g}$ of xylose per min.

\section{Protease assay}

Determination of protease production was done by incubating bacterial isolates in protease producing medium. The medium contained following composition per liter: yeast extract $5 \mathrm{~g}$, peptone $5 \mathrm{~g}$, glucose $5 \mathrm{~g}, \mathrm{Na}_{2} \mathrm{HPO}_{4}$ 0.4g, $\mathrm{Na}_{2} \mathrm{CO}_{3} 0.085 \mathrm{~g}, \mathrm{ZnSO}_{4} 0.02 \mathrm{~g}, \mathrm{MgSO}_{4} \mathrm{O} 0.02 \mathrm{~g}$ and adjusted to desired $\mathrm{pH}$. Broth was inoculated with $0.1 \mathrm{ml}$ of $12 \mathrm{~h}$ old culture and incubated at different temperature and $\mathrm{pH}$. After fermentation, broth medium was centrifuged at $10,000 \mathrm{rpm}$ for $15 \mathrm{~min}$ and cell free supernatant was used for enzyme assay.

Protease assay was done by using $2 \%$ casein in desired $\mathrm{pH}$ as substrate. Reaction mixture consisted $0.1 \mathrm{ml}$ casein buffer and $0.1 \mathrm{ml}$ crude enzyme, reaction was allowed to occur at $65{ }^{\circ} \mathrm{C}$ for $10 \mathrm{~min}$ in water bath. Afterward, reaction was stopped by adding $1 \mathrm{ml}$ of $10 \%$ trichloroacetic acid (TCA). The mixture was then centrifuged at 10,000 rpm for 20 min after centrifugation; protein content was estimated by Lowry et al. [19]. One unit of protease activity was defined as the amount of enzyme that is required for the release of $1 \mu$ mole tyrosine per min.

\section{Cellulase assay}

Cellulase production was assayed using cellulase producing medium that contained carboxymethyl cellulose (CMC) $5 \mathrm{~g}$, tryptone $2 \mathrm{~g}, \mathrm{~K}_{2} \mathrm{HPO}_{4} 4 \mathrm{~g}, \mathrm{Na}_{2} \mathrm{HPO}_{4} 4 \mathrm{~g}, \mathrm{MgSO}_{4} \cdot 7 \mathrm{H}_{2} \mathrm{O}$ o.2g, $\mathrm{CaCl}_{2} .2 \mathrm{H}_{2} \mathrm{O}$ 0.001g, $\mathrm{FeSO}_{4} .7 \mathrm{H}_{2} \mathrm{O}$ 0.004g. Each flask was inoculated with $12 \mathrm{~h}$ old culture and incubated at different temperature and $\mathrm{pH}$. Following prescribed incubation period, cell free supernatant was prepared by centrifugation method and used as a source of crude enzyme.

Cellulase assay was conducted following Miller [16]. Briefly, reaction mixture contained $0.75 \mathrm{ml}$ of buffer, $0.5 \mathrm{ml}$ of crude and $0.25 \mathrm{ml}$ substrate (1\% CMC buffer) solution; it was allowed to react at $45{ }^{\circ} \mathrm{C}$ for $30 \mathrm{~min}$ and then incorporated with $1.5 \mathrm{ml}$ of DNSA. All the tubes were then placed in boiling water bath for $10 \mathrm{~min}$. Absorbance of colour change was recorded at $540 \mathrm{~nm}$ by using a UV/Vis spectrophotometer (Ultraspec 2100 pro, Amersham Biosciences). One unit of enzyme is defined as the amount of enzyme required for the release of $1 \mu \mathrm{g}$ glucose per min.

\section{Protein estimation}

Total protein was estimated using Lowry's method [19].

\section{Ammonium sulfate precipitation}

The bacteria were grown in respective medium for obtaining desired amount of enzyme for its partial purification. After incubation, bacterial culture was centrifuged and cell free supernatant was subjected to ammonium sulfate precipitation at $4{ }^{\circ} \mathrm{C}$ (80 \% saturation). The precipitate was dissolved in minimal amount of respective buffer of active $\mathrm{pH}$ and then dialyzed overnight against same buffer at $4{ }^{\circ} \mathrm{C}$.

\section{Enzyme activity and stability}

Effect of temperature on the activity of thermophilic enzymes was observed by incubating reaction mixture at 
different temperatures, ranged from $10-100{ }^{\circ} \mathrm{C}$, in the preferred buffer system. Thermal stability of partially purified enzymes was observed by incubating crude enzyme at different temperatures for $1 \mathrm{~h}$. Afterward, residual activity was recorded by analyzing the enzyme reaction at optimum temperature in buffer of respective $\mathrm{pH}$ as described earlier.

To determine the optimal $\mathrm{pH}$ for enzyme activity, enzyme assays were performed in different buffer system ranging from 3-10 at optimum temperature. Similarly, for $\mathrm{pH}$ stability, enzyme was incubated in different buffers for one $h$ and residual activity was measured after performing standard enzyme assay at optimum $\mathrm{pH}$. Buffers (100 mmol) used for different $\mathrm{pH}$ include citrate buffer ( $\mathrm{pH} 3$ ), citrate phosphate buffer ( $\mathrm{pH} 4-5)$, sodium phosphate buffer ( $\mathrm{pH}$ 67), Tris-Cl (pH 8-9) and glycine-NaOH buffer ( $\mathrm{pH} 10$ ).

\section{Statistical analysis}

Variation in enzyme activities was estimated by one way ANOVA followed by post hoc Tukeys HSD test to find significant differences between enzyme production at different physiological cultural conditions. Mean and standard error of three replicates was calculated using Microsoft Excel 2007 software.

\section{RESULTS}

\section{Qualitative assays}

Results on the production of extracellular hydrolytic enzymes, measured in terms of hydrolysis of substrate viz. starch, lipid, xylan, cellulose and casein, are presented in table 2. All the isolates were capable of hydrolyzing starch and lipids, nine isolates were able to hydrolyze xylan and cellulose and seven isolates hydrolyzed casein. On the basis of the results obtained in qualitative assays, the efficient bacterial species were selected for further quantitative assays as follows: GBPI_25 for amylase, GBPI 3 for lipase, GBPI_25 for xylanase, GBPI_35 for protease and GBPI 4 for cellulase.

\section{Qualitative assays}

On the basis of zone of clearance, GBPI_25 was selected for the quantitative estimation of amylase enzymes. The effect of different temperature and $\mathrm{pH}$ on amylase production with biomass was measured using starch broth in static conditions. GBPI_25 was found to be an efficient producer of amylase in the temperature range from 45 to $65{ }^{\circ} \mathrm{C}$. Production of enzyme started after $24 \mathrm{~h}$ of incubation at all the temperatures while the maximum activity varied with respect to temperature and $\mathrm{pH}$. Maximum activity (1217.86 $\mathrm{U} / \mathrm{ml}$ ) of amylase enzyme was observed after $24 \mathrm{~h}$ at $45{ }^{\circ} \mathrm{C}$ and $5 \mathrm{pH}$ which showed significance difference $(\mathrm{p}<0.05)$ from other $\mathrm{pH}$ at same temperature (fig. 1). However, higher biomass production was achieved at $45{ }^{\circ} \mathrm{C}$ after $72 \mathrm{~h}$ of incubation at neutral $\mathrm{pH}$ (table 3).
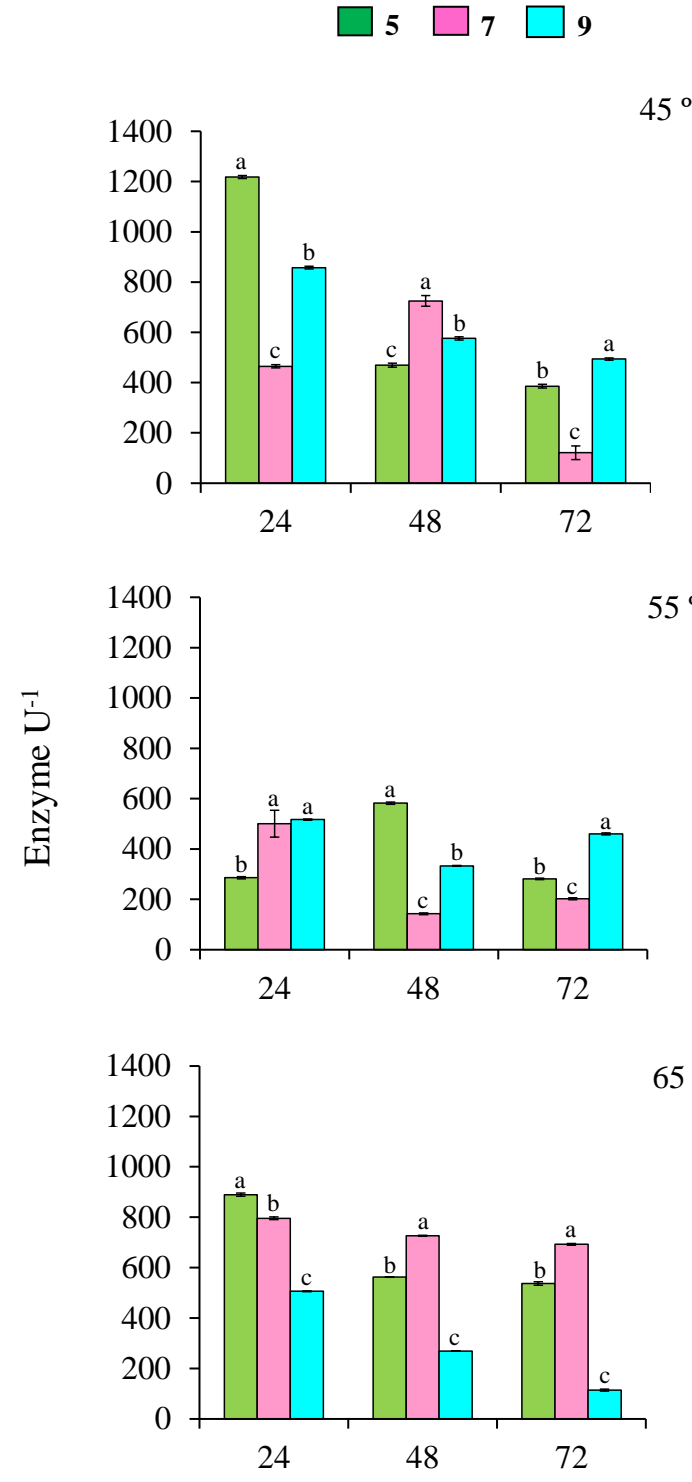

Incubation time $(\mathrm{h})$

Fig. 1: Amylase production by GBPI_25 at different temperature and pH. Different alphabets in a bar group indicate significant difference $(p<0.05)$. Error bar $=$ standard error $(n=3)$

Table 2: Qualitative estimation of extracellular enzymes produced by thermobacilli

\begin{tabular}{|c|c|c|c|c|c|c|}
\hline \multicolumn{7}{|c|}{ Zone of clearance (mm) } \\
\hline S. No. & Isolate Code & Amylase & Lipase & Xylanase & Cellulase & Protease \\
\hline 1 & GBPI 3 & ++ & +++ & + & ++ & - \\
\hline 2 & GBPI 4 & + & + & ++ & +++ & + \\
\hline 3 & GBPI 13 & + & + & + & ++ & - \\
\hline 4 & GBPI_16 & ++ & + & +++ & +++ & + \\
\hline 5 & GBPI_22 & + & + & - & + & + \\
\hline 6 & GBPI_25 & +++ & + & +++ & +++ & - \\
\hline 7 & GBPI_30 & +++ & + & + & + & + \\
\hline 8 & GBPI_31 & +++ & + & + & + & + \\
\hline 9 & GBPI_35 & +++ & + & + & - & ++ \\
\hline 10 & GBPI_37 & ++ & + & + & + & + \\
\hline
\end{tabular}

$(-=$ no zone $,+=<2 \mathrm{~mm},++=3-5 \mathrm{~mm},+++=>5 \mathrm{~mm})$ 
Table 3: Biomass production by thermobacilli at different temperature and pH

\begin{tabular}{|c|c|c|c|c|c|c|}
\hline \multirow[t]{2}{*}{ Enzyme } & \multirow[t]{2}{*}{ Isolate code } & \multirow[t]{2}{*}{ Temp. $\left({ }^{\circ} \mathrm{C}\right)$} & \multirow[t]{2}{*}{$\mathbf{p H}$} & \multicolumn{3}{|c|}{ Bacterial biomass (O. D. at $600 \mathrm{~nm}$ ) } \\
\hline & & & & $24 \mathrm{~h}$ & $48 \mathrm{~h}$ & $72 \mathrm{~h}$ \\
\hline \multirow{10}{*}{ Amylase } & \multirow{10}{*}{ GBPI_25 } & \multirow{4}{*}{45} & 5 & $0.081 \pm 0.004^{a}$ & $0.091 \pm 0.003^{a}$ & $0.169 \pm 0.005^{b}$ \\
\hline & & & 7 & $0.077 \pm 0.004^{\mathrm{a}}$ & $0.032 \pm 0.009^{b}$ & $0.226 \pm 0.009^{a}$ \\
\hline & & & 9 & $0.018 \pm 0.001^{b}$ & $0.091 \pm 0.004^{\mathrm{a}}$ & $0.186 \pm 0.004^{b}$ \\
\hline & & & 5 & $0.109 \pm 0.001^{\mathrm{a}}$ & $0.077 \pm 0.012^{b}$ & $0.126 \pm 0.001^{b}$ \\
\hline & & \multirow[t]{3}{*}{55} & 7 & $0.093 \pm 0.008^{a}$ & $0.126 \pm 0.009^{a}$ & $0.176 \pm 0.003^{\mathrm{a}}$ \\
\hline & & & 9 & $0.017 \pm 0.010^{b}$ & $0.052 \pm 0.001^{b}$ & $0.052 \pm 0.004^{\mathrm{c}}$ \\
\hline & & & 5 & $0.056 \pm 0.001^{\mathrm{a}}$ & $0.048 \pm 0.003^{c}$ & $0.146 \pm 0.009^{b}$ \\
\hline & & \multirow[t]{3}{*}{65} & 7 & $0.025 \pm 0.003^{c}$ & $0.077 \pm 0.001^{b}$ & $0.045^{ \pm 0.002^{\mathrm{c}}}$ \\
\hline & & & 9 & $0.042 \pm 0.001^{b}$ & $0.124 \pm 0.002^{\mathrm{a}}$ & $0.220 \pm 0.005^{\mathrm{a}}$ \\
\hline & & & 5 & $0.162 \pm 0.006^{b}$ & $0.252 \pm 0.007^{a}$ & $0.400 \pm 0.006^{b}$ \\
\hline \multirow[t]{9}{*}{ Lipase } & \multirow[t]{9}{*}{ GBPI3 } & \multirow[t]{3}{*}{45} & 7 & $0.217 \pm 0.012^{\mathrm{a}}$ & $0.155^{ \pm 0.003^{b}}$ & $0.197 \pm 0.003^{c}$ \\
\hline & & & 9 & $0.043 \pm 0.009^{c}$ & $0.171 \pm 0.007^{b}$ & $0.707 \pm 0.007^{\mathrm{a}}$ \\
\hline & & & 5 & $0.012 \pm 0.002^{c}$ & $0.283 \pm 0.005^{\mathrm{a}}$ & $0.282 \pm 0.007^{\mathrm{a}}$ \\
\hline & & \multirow[t]{3}{*}{55} & 7 & $0.046 \pm 0.008^{b}$ & $0.096 \pm 0.003^{b}$ & $0.145^{ \pm 0.005^{c}}$ \\
\hline & & & 9 & $0.533 \pm 0.005^{\mathrm{a}}$ & $0.107 \pm 0.005^{b}$ & $0.732 \pm 0.010^{c}$ \\
\hline & & & 5 & $0.010 \pm 0.005^{c}$ & $0.027 \pm 0.005^{b}$ & $0.225 \pm 0.001^{\mathrm{a}}$ \\
\hline & & \multirow[t]{3}{*}{65} & 7 & $0.127 \pm 0.006^{b}$ & $0.039 \pm 0.004^{b}$ & $0.109 \pm 0.004^{c}$ \\
\hline & & & 9 & $0.230 \pm 0.003^{a}$ & $0.190 \pm 0.003^{\mathrm{a}}$ & $0.128 \pm 0.003^{b}$ \\
\hline & & & 5 & $0.088 \pm 0.005^{b}$ & $0.111 \pm 0.001^{b}$ & $1.203 \pm 0.004^{\mathrm{a}}$ \\
\hline \multirow[t]{9}{*}{ Xylanase } & \multirow[t]{9}{*}{ GBPI_25 } & \multirow[t]{3}{*}{45} & 7 & $0.118 \pm 0.007^{\mathrm{a}}$ & $0.190 \pm 0.005^{\mathrm{a}}$ & $0.093^{ \pm 0.001^{\mathrm{c}}}$ \\
\hline & & & 9 & $0.056 \pm 0.002^{c}$ & $0.229 \pm 0.006^{a}$ & $0.314 \pm 0.001^{b}$ \\
\hline & & & 5 & $0.061 \pm 0.001^{\mathrm{c}}$ & $0.107 \pm 0.001^{\mathrm{a}}$ & $0.181 \pm 0.001^{b}$ \\
\hline & & \multirow[t]{3}{*}{55} & 7 & $0.190 \pm 0.005^{\mathrm{a}}$ & $0.085 \pm 0.007^{\mathrm{b}}$ & $0.138 \pm 0.004^{c}$ \\
\hline & & & 9 & $0.087 \pm 0.001^{b}$ & $0.054 \pm 0.001^{c}$ & $0.209 \pm 0.005^{\mathrm{a}}$ \\
\hline & & & 5 & $0.055 \pm 0.003^{b}$ & $0.099 \pm 0.001^{b}$ & $0.132 \pm 0.001^{b}$ \\
\hline & & \multirow[t]{3}{*}{65} & 7 & $0.093 \pm 0.001^{\mathrm{a}}$ & $0.111 \pm 0.001^{\mathrm{ab}}$ & $0.150 \pm 0.003^{\mathrm{a}}$ \\
\hline & & & 9 & $0.021 \pm 0.004^{c}$ & $0.115 \pm 0.005^{\mathrm{a}}$ & $0.149 \pm 0.004^{a}$ \\
\hline & & & 5 & $0.296 \pm 0.006^{a}$ & $0.204 \pm 0.001^{\mathrm{a}}$ & $0.118 \pm 0.003^{a}$ \\
\hline \multirow[t]{9}{*}{ Protease } & \multirow[t]{9}{*}{ GBPI_35 } & 45 & 7 & $0.139 \pm 0.003^{b}$ & $0.093 \pm 0.002^{b}$ & $0.016 \pm 0.002^{c}$ \\
\hline & & & 9 & $0.135^{ \pm 0.001^{b}}$ & $0.089 \pm 0.005^{b}$ & $0.166 \pm 0.004^{b}$ \\
\hline & & & 5 & $0.167 \pm 0.007^{b}$ & $0.213 \pm 0.007^{\mathrm{a}}$ & $0.224 \pm 0.001^{b}$ \\
\hline & & 55 & 7 & $0.312 \pm 0.001^{\mathrm{a}}$ & $0.116 \pm 0.001^{b}$ & $0.015 \pm 0.001^{\mathrm{c}}$ \\
\hline & & & 9 & $0.135^{ \pm 0.006^{c}}$ & $0.224 \pm 0.006^{a}$ & $0.260 \pm 0.001^{\mathrm{a}}$ \\
\hline & & & 5 & $0.034 \pm 0.005^{b}$ & $0.032 \pm 0.001^{b}$ & $0.067 \pm 0.001^{b}$ \\
\hline & & 65 & 7 & $0.012 \pm 0.001^{\mathrm{c}}$ & $0.045^{ \pm 0.006^{b}}$ & $0.026 \pm 0.001^{c}$ \\
\hline & & & 9 & $0.233 \pm 0.003^{a}$ & $0.247 \pm 0.003^{\mathrm{a}}$ & $0.720 \pm 0.006^{a}$ \\
\hline & & & 5 & $0.015^{ \pm 0.001^{b}}$ & $0.009 \pm 0.003^{b}$ & $0.138 \pm 0.001^{c}$ \\
\hline Cellulase & GBPI 4 & 45 & 7 & $0.055^{ \pm 0.001^{\mathrm{a}}}$ & $0.096 \pm 0.006^{a}$ & $0.375^{ \pm 0.005^{a}}$ \\
\hline & & & 9 & $0.018 \pm 0.001^{b}$ & $0.020 \pm 0.001^{b}$ & $0.316 \pm 0.007^{b}$ \\
\hline & & & 5 & $0.013 \pm 0.001^{\mathrm{c}}$ & $0.069 \pm 0.004^{b}$ & $0.046 \pm 0.002^{b}$ \\
\hline & & 55 & 7 & $0.085 \pm 0.001^{\mathrm{a}}$ & $0.093 \pm 0.001^{\mathrm{a}}$ & $0.054 \pm 0.003^{b}$ \\
\hline & & & 9 & $0.024 \pm 0.001^{b}$ & $0.066 \pm 0.001^{b}$ & $0.104 \pm 0.001^{\mathrm{a}}$ \\
\hline & & & 5 & $0.011 \pm 0.000^{b}$ & $0.067 \pm 0.004^{\mathrm{a}}$ & $0.044 \pm 0.002^{\mathrm{c}}$ \\
\hline & & 65 & 7 & $0.031 \pm 0.001^{\mathrm{a}}$ & $0.045 \pm 0.001^{\mathrm{b}}$ & $0.201 \pm 0.003^{a}$ \\
\hline & & & 9 & $0.012 \pm 0.001^{b}$ & $0.034 \pm 0.001^{c}$ & $0.173^{ \pm 0.001^{b}}$ \\
\hline
\end{tabular}

Values are mean $\pm \mathrm{SE}$ of triplicates. Mean with different alphabets are significantly different on same incubation time

GBPI3 showed lipase production at all the temperature and $\mathrm{pH}$ conditions while higher concentration of enzyme was recorded at $\mathrm{pH} 9$ at all the temperatures. At $65{ }^{\circ} \mathrm{C}$, maximum amount of enzyme $(22.59 \mathrm{U} / \mathrm{ml})$ was achieved after $48 \mathrm{~h}$ of incubation, which was significantly different (p<0.05) from other pH (fig. 2). Maximum cell biomass was recorded at the optimum growth temperature $\left(55{ }^{\circ} \mathrm{C}\right)$ and $\mathrm{pH}$ (9), after $72 \mathrm{~h}$ of incubation.

Considering the good observation on xylanase production in qualitative assays, GBPI_25 was subjected for its quantitative estimation at temperature ranged from 45 to $65{ }^{\circ} \mathrm{C}$ and $\mathrm{pH} 5$ to 9 . Enzyme production was observed after $24 \mathrm{~h}$ of incubation, although the higher activity varied with different temperature and $\mathrm{pH}$. The significantly higher (<0.05) amount $(98.07 \mathrm{U} / \mathrm{ml})$ of xylanase was found at $9 \mathrm{pH}$ and $45^{\circ} \mathrm{C}$ after $48 \mathrm{~h}$ of incubation. Biomass was produced maximum after $72 \mathrm{~h}$ of incubation at $45{ }^{\circ} \mathrm{C}$ and $\mathrm{pH}$ 9. The time course of xylanase production by GBPI_25 is shown in Fig.3.

In case of protease enzyme, maximum zone of clearance was recorded in the thermophilic isolate GBPI_35. Minimum enzyme activity $0.42 \mathrm{U} / \mathrm{ml}$ was revealed at the optimum growth temperature $\left(55^{\circ} \mathrm{C}\right)$ and in acidic $\mathrm{pH}(5)$. Maximum enzyme activity $(16.66 \mathrm{U} / \mathrm{ml})$ was observed at $55{ }^{\circ} \mathrm{C}$ after $24 \mathrm{~h}$ incubation under alkaline $\mathrm{pH}$ (9) which was significantly different $(\mathrm{p}<0.05)$ from $\mathrm{pH} 5$ and 7 (fig. 4). The maximum biomass was recorded at $65{ }^{\circ} \mathrm{C}$ and $\mathrm{pH} 9$ after $72 \mathrm{~h}$ of incubation (table 3 ).

Out of three temperatures, GBPI 4 showed increased cellulase production at suboptimal growth temperature $\left(45{ }^{\circ} \mathrm{C}\right)$ 
followed by production at $55{ }^{\circ} \mathrm{C}$ under acidic ( $\mathrm{pH}$ 5) environment. In case of $65{ }^{\circ} \mathrm{C}$, GBPI 4 showed decrease in production of cellulase enzyme at all the $\mathrm{pH}$ conditions. The maximum enzyme production i.e. $108.68 \mathrm{U} / \mathrm{ml}$ was achieved at $45^{\circ} \mathrm{C}$ and $\mathrm{pH} 5$ conditions after $72 \mathrm{~h}$ of incubation which was significantly different $(\mathrm{p}<0.05)$ from the other $\mathrm{pH}$ under consideration, but at the same temperature in static conditions. The minimum production $(2.34 \mathrm{U} / \mathrm{ml})$ of cellulase was recorded at $65^{\circ} \mathrm{C}$ (fig. 5). The higher concentration of cell biomass was produced at $45^{\circ} \mathrm{C}$ and $\mathrm{pH} 9$ after $72 \mathrm{~h}$ (table 3 ).

\section{Enzyme activity and stability}

The amylase extracted from GBPI_25 showed a wide temperature range $\left(10-90{ }^{\circ} \mathrm{C}\right)$ with maximum activity at $50{ }^{\circ} \mathrm{C}$ that got decreased subsequently. However, the enzyme exhibited maximum $(87.52 \%)$ stability at $40{ }^{\circ} \mathrm{C}$ after $1 \mathrm{~h}$ of incubation (fig. 6A). Optimum $\mathrm{pH}$ for amylase activity was recorded between 5 to 7 , and being maximum at 5 (Fig.6B).

In case of lipase, GBPI 3 possessed wide range of temperature $\left(10-80{ }^{\circ} \mathrm{C}\right)$ as presented in fig. 6C. Both the enzyme activity as well as the stability was found maximum at $40{ }^{\circ} \mathrm{C}$. Optimum $\mathrm{pH}$ for activity as well as the stability of lipase was recorded at 5 (fig. 6D).

The xylanase extracted from the thermophilic isolate GBPI_25 exhibited temperature range between 10 to $100{ }^{\circ} \mathrm{C}$ for its activity as well as stability. The enzyme was more active at $50^{\circ} \mathrm{C}$ followed by $40^{\circ} \mathrm{C}(96.60 \%)$ while maximum stability was obtained at $40^{\circ} \mathrm{C}$. Above and below $40^{\circ} \mathrm{C}$, the stability of xylanase was found to be decreasing continuously. Similar to amylase enzyme from the same bacterial isolate, it also exhibited maximum activity and stability at $\mathrm{pH} 5$. Effect of temperature and $\mathrm{pH}$ on the activity as well as stability of xylanase are presented in fig. 6EandF, respectively.

The optimum temperature of protease enzyme activity isolated from GBPI_35 was found to be maximum at 60 ${ }^{\circ} \mathrm{C}$, and as the temperature raised or declined there was decrease in enzyme activity. However, maximum enzyme stability was recorded at $40^{\circ} \mathrm{C}$ (fig. 6G). Highest protease activity and stability was obtained at $5 \mathrm{pH}$ (fig. $6 \mathrm{H}$ ).

Maximum activity of cellulose produced by GBPI 4 was revealed at $50{ }^{\circ} \mathrm{C}$. Further increase in temperature resulted in decreased activity of the enzyme. On the other hand, stability of cellulase was recorded at $40{ }^{\circ} \mathrm{C}$. Cellulase also showed similar stability at 30 and $60{ }^{\circ} \mathrm{C}$ (fig. 6I). This enzyme showed the highest activity as well as stability at neutral (7) pH (fig. 6J).

Microorganisms from extreme climatic conditions are being recognized as potential source of commercially important enzymes. Thermozymes, in particular, bear numerous advantages over mesophilic enzymes such as the activity and effectiveness under extreme temperature, $\mathrm{pH}$, pressure and high substrate concentration [20]. The present study deals with the role of temperature and $\mathrm{pH}$ on the production of different thermozymes for their biotechnological applications as well as ecological resilience aspects.

The production of amylase enzyme from GBPI_25 showed higher activity at suboptimal growth temperature $\left(45^{\circ} \mathrm{C}\right)$ and acidic $\mathrm{pH}$ after $24 \mathrm{~h}$ of incubation. Similar incubation temperature and time was reported in earlier studies in Bacillus sp. and in B. licheniformis [21, 22], respectively.
Production of the higher concentration of amylase under the influence of temperature in acidic as well as alkaline conditions has been reported [23, 24]. The $\mathrm{pH}$ optima, in the present study, for enzyme activity and stability was similar as described by Asoodeh et al. [25]. Geobacillus stearothermophilus $\mathrm{HP}_{3}$ has been reported for production of novel thermostable and alkali tolerant amylase [26]. Amylase production by Geobacillus sp. GJA1 isolated from a hot spring located in Tapovan area of Uttarakhand (IHR) has also been studied by Jugran et al. [27]. In comparison to neutral $\alpha$-amylases; acid stable amylases have $30 \%$ less acidic and basic amino acids which play key role in protection of electrostatic repulsion of charged groups at acidic condition, and help in the stability of the protein and reduces risk of contamination. The major drawback of most of the known acid stable amylases is that they lack thermostability at high temperature, while present study showed maximum stability at $50{ }^{\circ} \mathrm{C}$ which is likely to be helpful in reducing this drawback [5].
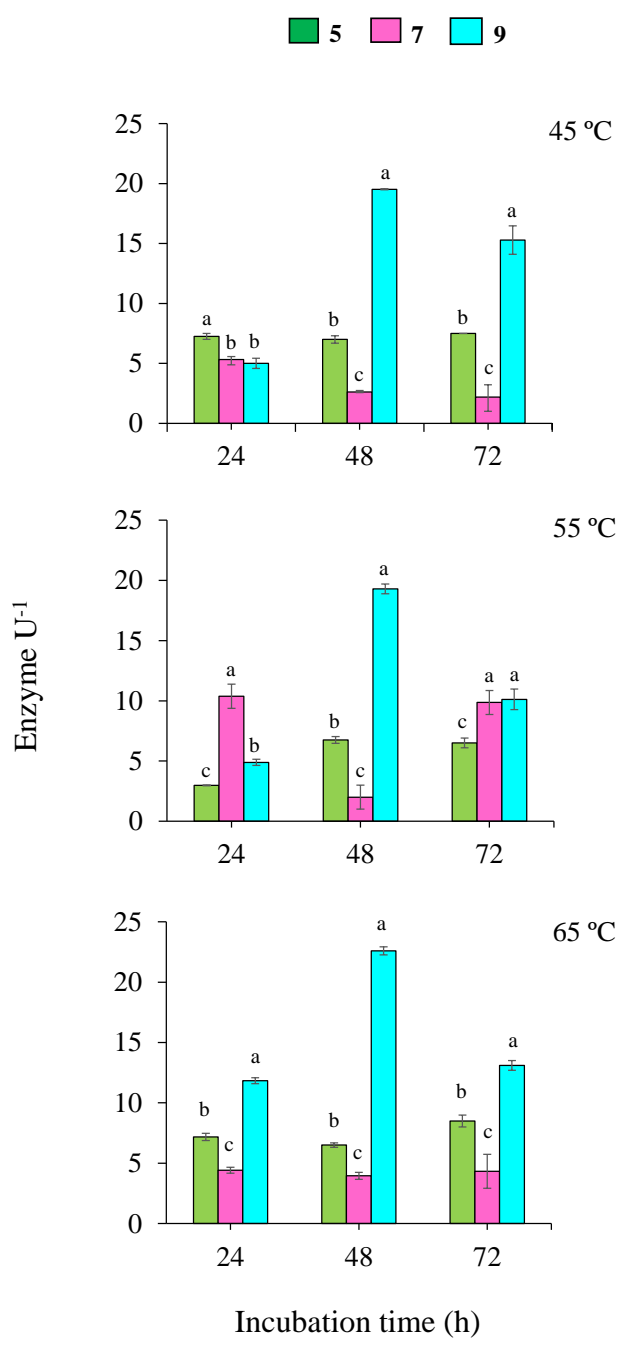

Fig. 2: Lipase production by GBPI 3 at different temperature and pH. Different alphabets in a bar group indicate significant difference $(p<0.05)$. Error bar $=$ standard error $(n=3)$ 

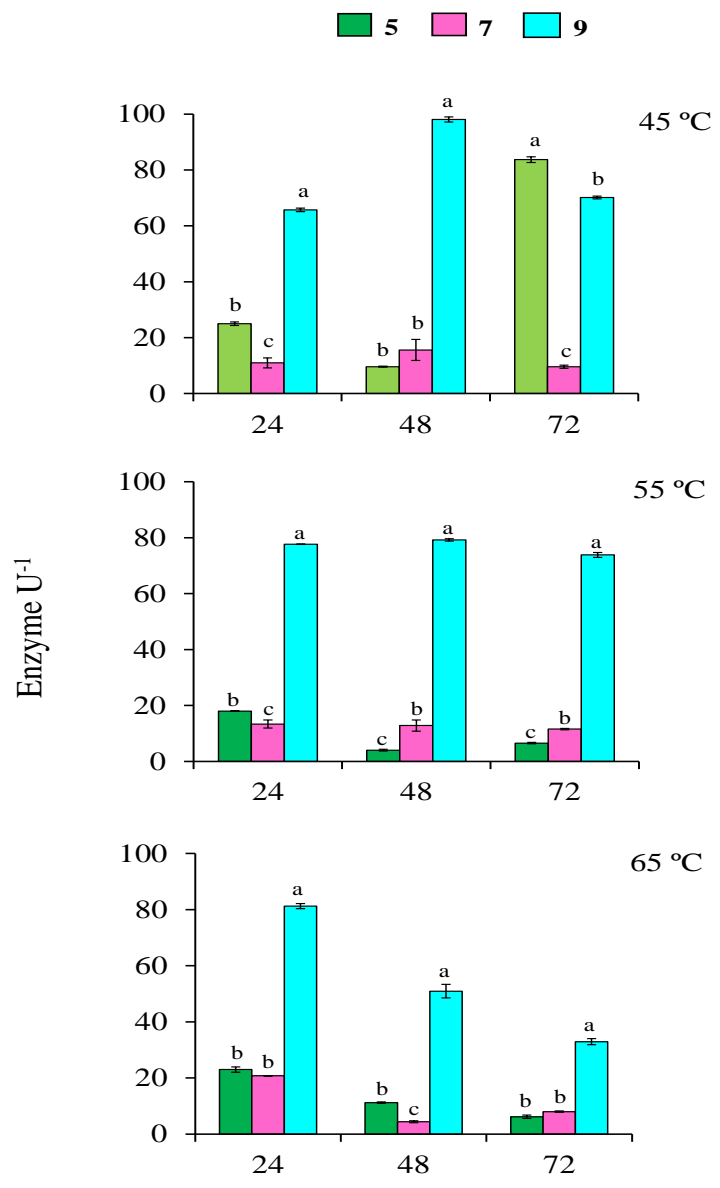

Incubation time (h)

Fig. 3: Xylanase production by GBPI_25 at different temperature and $\mathrm{pH}$. Different alphabets in a bar group indicate significant difference $(p<0.05)$. Error bar $=$ standard error $(n=3)$

Lipase production from GBPI 3 was observed higher at their suboptimal $\left(65^{\circ} \mathrm{C}\right)$ temperature and alkaline $\mathrm{pH}$ (9). The identical temperature for lipase production was reported from G. stearothermophilus [10], while $60{ }^{\circ} \mathrm{C}$ was optimum temperature for lipase production reported from $G$. thermleovorance [28] and Aneurinibacillus thermoaerophilus [29]. Berekaa et al. [30] reported that the production of lipase enzyme from thermophilic bacteria occurred maximally between temperatures 50 to $70{ }^{\circ} \mathrm{C}$. Similar pH was also documented in thermophilic Anoxybacillus flavithermus [31] as well as in psychrophilic strain of Pseudomonas proteolytica [32]. Crude lipase was found active along a wide temperature and $\mathrm{pH}$ range and similar range of $\mathrm{pH}$ was also reported in a thermo-alkaline Staphylococcus aureus by Bacha et al. [33]. Maximum stability and activity in lipase production was also recorded at suboptimal culture $\left(40{ }^{\circ} \mathrm{C}\right.$ temperature and $\left.5 \mathrm{pH}\right)$ conditions which is similar to lipase from Pseudomonas gessardii [34]. According to Ramani et al. [34], at this $\mathrm{pH}$ and temperature, lipase was suitable for adsorption on the oil-water interface and helpful in the opening of block lid from the active site of the enzyme to lower the activation energy of hydrolysis.
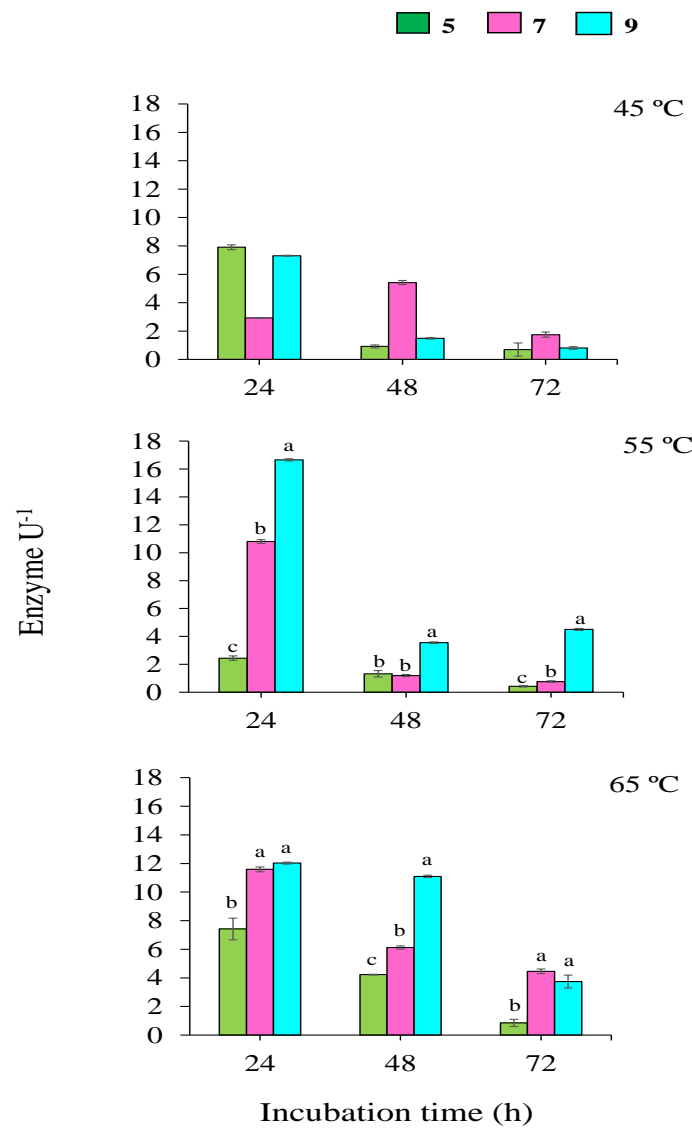

Fig. 4: Protease production by GBPI_35 at different temperature and $\mathrm{pH}$. Different alphabets in a bar group indicate significant difference $(\mathbf{p}<0.05)$. Error bar $=$ standard error $(n=3)$
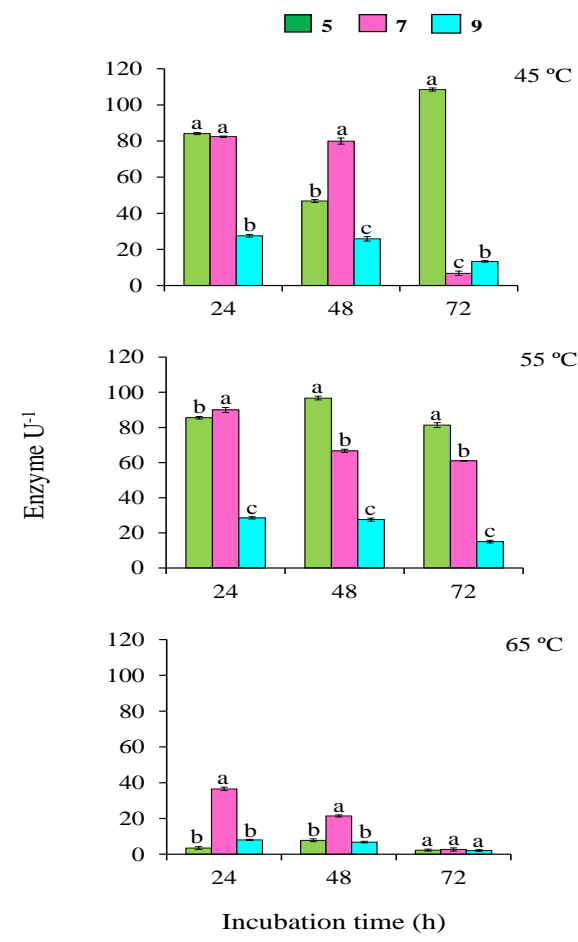

Fig. 5: Cellulase production by GBPI 4 at different temperature and $\mathrm{pH}$. Different alphabets in a bar group indicate significant difference $(p<0.05)$. Error bar $=$ standard error $(n=3)$ 


\section{DISCUSSION}

The present study showed higher production of xylanase at alkaline $\mathrm{pH}$. However, different optimum temperature has been observed in various thermophilic isolates namely $G$. stearothermophilus and $B$. halodurans $[35,36]$. Xylanase from bacterial sources are active and stable in a wide range of $\mathrm{pH}$ and temperature conditions. Xylanase enzyme exhibited its optimal activity at wide range of incubation conditions, such as temperature from 30 to $60{ }^{\circ} \mathrm{C}$ and $\mathrm{pH}$ from 5.0 to 9.0 [37]. The present investigation revealed difference between the optimum culture conditions for enzyme production and its activity. Similar observations were also observed in B. mojavansis [38].

In case of protease enzyme secreted by thermophilic isolates GBPI_35, the temperature profile showed higher production at their optimum growth temperature i.e. $55^{\circ} \mathrm{C}$ and alkaline $\mathrm{pH}$ conditions. A number of studies have indicated that the optimum production of protease enzyme occur at identical alkaline $\mathrm{pH}$ under different temperature conditions [39, 40]. According to Hadder et al. [41], protease enzyme having high temperature and alkaline $\mathrm{pH}$ activity make it ideal for detergent industries. However, enzyme activity and stability, observed in present study, is entirely different from the previous studies [38, 42].

In case of cellulase, GBPI4 produced higher concentration at acidic $\mathrm{pH}$ and $45{ }^{\circ} \mathrm{C}$. The same $\mathrm{pH}$ was also recorded in Gluconacetobacter sp. Gel_SEA623-2 by Kim et al. [43]. However, in most of the cases maximum production of cellulase was recorded in alkaline $\mathrm{pH}[44,45]$. Partially purified enzyme showed wide temperature and $\mathrm{pH}$ range for its activity and stability with optimum $50{ }^{\circ} \mathrm{C}$ and acidic $\mathrm{pH}$ 7. In high temperature as well as mild alkaline conditions, production of cellulase may be useful in industrial applications [46].

\section{CONCLUSION}

In the present investigation, different thermophilic isolates have been screened and demonstrated for their ability to produce enzymes at varying $\mathrm{pH}$ and temperature conditions. Preliminary screening of such microorganisms that are isolated from extreme environments is essential in view of harnessing their economic importance. Promising strains can be further engineered using advance technologies for their commercial utilization. All the thermophilic bacteria under study showed unusual properties to tolerate wide range of $\mathrm{pH}$ and temperature which may be beneficial in a number of biotechnology based industries.

\section{ACKNOWLEDGEMENT}

Authors gratefully acknowledge the Director of G. B. Pant National Institute of Himalayan Environment and Sustainable Development, India for extending the facilities and Ministry of Environment, Forest and Climate Change, Govt. of India, New Delhi for financial support. SAS and AP acknowledge the support of Department of Science and Technology, Govt. of India, New Delhi and Federation of Indian Chambers of Commerce and Industry for awarding the CV Raman International Fellowships for African Researchers.

\section{CONFLICT OF INTERESTS}

The authors declare that there is no conflict of interest
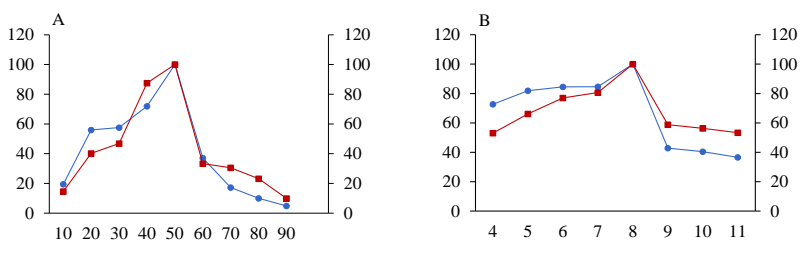

GBPI_25 (Amylase)
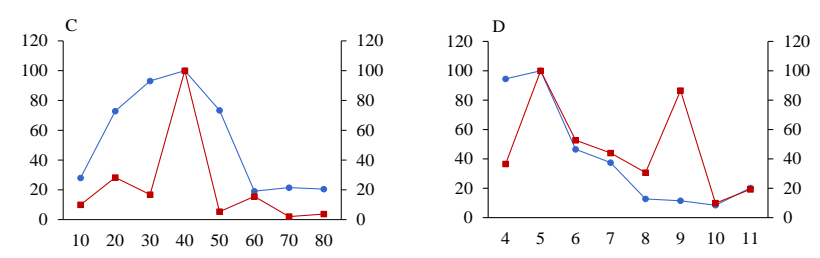

GBPI 3 (Lipase)
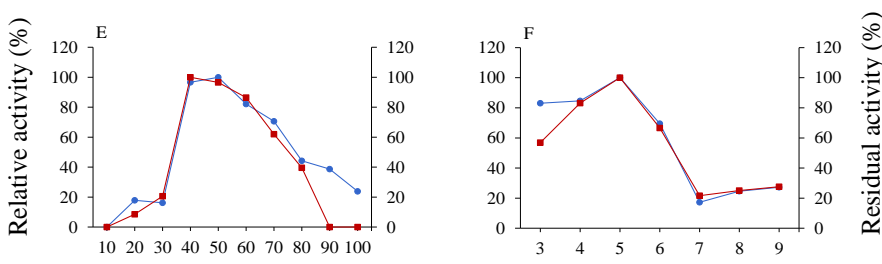

GBPI_25 (Xylanase)
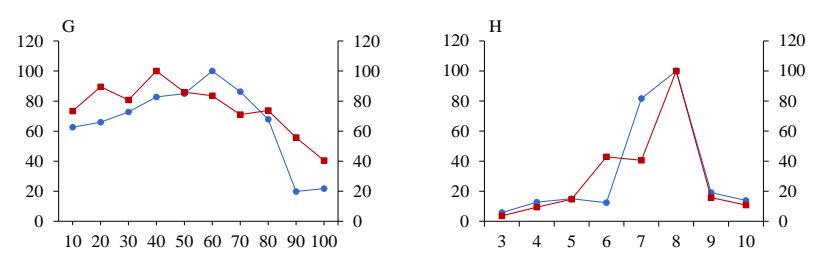

GBPI_35 (Protease)
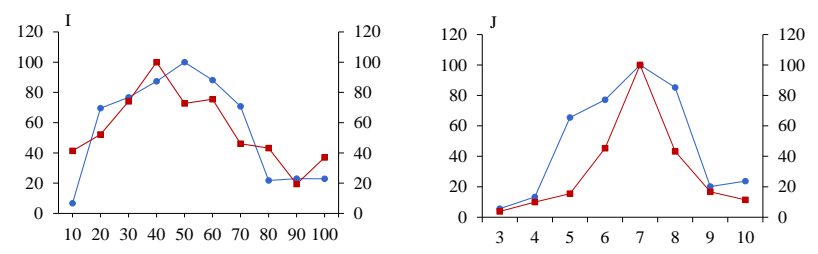

GBPI 4 (Cellulase)

Temperature $\left({ }^{\circ} \mathrm{C}\right)$

pH

- Relative activity (\%)

Residual activity $(\%)$

Fig. 6: Effect of temperature and $\mathrm{pH}$ on activity and stability of thermozymes produced by

thermophilic bacterial species (AandB) GBPI_25

(amylase), (CandD) GBPI 3 (Lipase), (EandF)

GBPI_25 (Xylanase), (GandH) GBPI_25

(Protease), (IandJ) GBPI_25 (Cellulase)

\section{REFERENCES}

1. Dewan S. Global Markets for Enzymes in Industrial Applications. BCC Research, Wellesley, MA. USA, 2014. 
2. Li S, Yang X, Yang S, Zhu M, Wang X. Technology prospecting on enzymes: application, marketing and engineering. Compututational and Structural Biotechnology Journal. 2012;2:1-11.

3. Nigam PS. Microbial enzymes with special characteristics for biotechnological applications. Biomolecules. 2013;3:597-611.

4. Dumorne K, Cordova DC, Astorga-Elo M, Renganathan P. Extremozymes: A potential source for industrial applications. Journal of Microbiology Biotechnology. 2017;27: 649-659.

5. Sharma A, Satyanarayana T. Microbial acid-stable $\alpha-$ amylases: Characteristics, genetic engineering and applications. Process Biochemistry. 2013;48:201-211.

6. Kumar B, Trivedi P, Mishra AK, Pandey A, Palni LMS. Microbial Diversity of soil from two Hot Springs in Garhwal Himalaya. Microbiological Research. 2004;159:141-146.

7. Kumar B, Pandey A, Palni LMS. Extracellular amylase activity of Saccharomycopsis fibuligera, a mycelial yeast isolated from a hot spring site in Garhwal Himalayas. Indian Journal of Microbiology. 2005;45:211-215.

8. Trivedi P, Kumar B, Pandey A. Conservation of soil microbial diversity associated with two hot springs in Uttaranchal Himalaya. National Academy Science Letters. 2006;29(5and6):185-188.

9. Bhardwaj KN, Tiwari SC, Pandey A. Conservation of thermophilic cyanobacterial diversity and physicochemical characteristics of thermal springs of Tapoban geothermal field, Himalayan province (India). National Academy Science Letters. 2011;34(3and4):77-82.

10. Pandey A, Dhakar K, Sati P, Sharma A, Kumar B, Palni LMS. Geobacillus stearothermophilus (GBPI_16): A resilient hyperthermophile isolated from an autoclaved sediment sample. Proceedings of National Academy Science, India, Section B. 2014;84:349-356.

11. Arya M, Joshi GK, Gupta AK, Raturi A. Isolation and characterization of thermophilic bacterial strains from Soldhar (Tapovan) hot spring in Central Himalayan Region, India. Annals of Microbiology. 2015;65(3): 1457-1464.

12. Francis F, Sabu A, Nampoothiri KM, Ramachandran S, Ghosh S, Szakacs G, Pandey A. Use of response surface methodology for optimizing process parameters for the production of $\alpha$-amylase by Aspergillus oryzae. Biochemical Engineering Journal. 2003;15:107-115.

13. Sharma A, Pandey A, Shouche YS, Kumar B, Kulkarni G. Characterization and identification of Geobacillus spp. isolated from Soldhar hot spring site of Garhwal Himalaya, India. Journal of Basic Microbiology. 2009;48:187-194.

14. Pandey A, Dhakar K, Sharma A, Priti P, Sati P, Kumar B. Thermophilic bacteria that tolerate a wide temperature and $\mathrm{pH}$ range colonize the Soldhar (95 $\left.{ }^{\circ} \mathrm{C}\right)$ and Ringigad $\left(80^{\circ} \mathrm{C}\right)$ hot springs of Uttarakhand, India. Annals of Microbiology. 2015;65:809-816.

15. Dhyani A, Jain R, Pandey A, Sharma A, Dhakar K, Pande V. Diauxic growth pattern in thermophilic Bacillus spp. with respect to production of thermostable amylase. Journal of Current Microbiology (in press). 2017.

16. Miller GL. 1959. Use of dinitrosalicylic acid reagent for determination of reducing sugar. Analytical Chemistry. 1959;31:426-428.
17. Pinsirodom P, Parkin KL. Current protocols in food analytical chemistry. Wiley, New York. 2001.

18. Bailey MJ, Biely $\mathrm{P}$, Poutanen K. Interlaboratory testing of methods for assay of xylanases activity. Journal of Biotechnology. 1992;25:257-270.

19. Lowry $\mathrm{OH}$, Rosebrough NJ, Farr AL, Randall RJ. Protein measurement with the folin phenol reagent. Journal of Biological Chemistry. 1951;193:265-275.

20. Sarmiento F, Peralta R, Blamey JM. Cold and hot extremozymes: industrial relevance and current trends. Frontiers in Bioengineering and Biotechnology. 2014;3:148.

21. Liu XD, Xu Y. A novel raw starch digesting $\alpha$-amylase from a newly isolated Bacillus sp. YX-1:Purification and characterization. Bioresource Technology. 2008;99:4315-4320.

22. Fincan SA, Enze B, Ozdemir S, Bekler FM. Purification and characterization of thermostable $\alpha$-amylase from thermophilic Anoxybacillus flavithermus. Carbohydrate Polymers. 2014;102:144-150.

23. Deb P, Talukdar SA, Mohsina K, Sarker PK, Sayem SMA. Production and partial characterization of extracellular amylase enzyme from Bacillus amyloliquefaciens P-oo. Springer Plus. 2013;154:1-12.

24. Roy JK, Mukherjee AK. Applications of a high maltose forming, thermo-stable-amylase from an extremely alkalophilic Bacillus licheniformis strain ASo8E in food and laundry detergent industries. Biochemical Engineering Journal. 2013;77:220-230.

25. Asoodeh A, Chamani JK, Lagzian M. A novel thermostable, acidophilic $\alpha$-amylase from a new thermophilic "Bacillus sp. Ferdowsicous" isolated from Ferdows hot mineral spring in Iran: Purification and biochemical characterization. International Journal of Biological Macromolecules. 2010;46:289297.

26. Selim SA. Novel thermostable and alkali tolerant amylase production by Geobacillus stearothermophilus $\mathrm{HP}_{3}$. Natural Products Research. 2011;26:1626-1630.

27. Jugran J, Rawat N, Joshi GK. Amylase production by Geobacillus sp. GJA1 isolated from a hot spring in Uttarakhand. ENVIS Bulletin Himalayan Ecology. 2015;23:21-26.

28. Abol-Fotouh DM, Bayoumi RA, Hassan MA. Production of thermoalkaliphilic lipase from Geobacillus thermoleovorans DA2 and application in leather industry. Enzyme Research. 2016;Article ID 9034364 .

29. Masomian M, Rahman RNZA, Salleh AB, Basri M. A unique thermostable and organic solvent tolerant lipase from newly isolated Aneurinibacillus thermoaerophilus strain HZ: physical factor studies. World Journal of Microbiology and Biotechnology. 2010;26:1693-1701.

30. Berekaa MM, Zaghloul TI, Abdel-Fattah YR, Saeed HM, Sifour M. Production of a novel glycerolinducible lipase from thermophilic Geobacillus stearothermophilus strain-5. World Journal of Microbiology and Biotechnology. 2009;25:287-294.

31. Bakir ZB, Metin K. Purification and characterization of an alkali-thermostable lipase from thermophilic Anoxybacillus flavithermus HBB 134. Journal of Microbiology and Biotechnology. 2016;26:1087-1097.

32. Jain R, Pandey A, Pasupuleti M, Pande V. Prolonged production and aggregation complexity of cold-active lipase from Pseudomonas proteolytica (GBPI_Hb61) 
isolated from cold desert Himalaya. Molecular Biotechnology. 2017;59:34-45.

33. Bacha AB, Al-assaf A, Moubayed NMS, Abid I. Evaluation of a novel thermo-alkaline Staphylococcus aureus lipase for application in detergent formulations. Saudi Journal of Biological Sciences. 2018;25:409-417.

34. Ramani K, Kennedy LJ, Ramakrishnan M, Sekhran G. Purification, characterization and application of acidic lipase from Pseudomonas gessardii using beef tallow as a substrate for fats and oil hydrolysis. Process Biochemistry. 2010;45:1683-1691.

35. Kamble RD, Jadav AR. Isolation, purification, and characterization of xylanase produced by a new species of Bacillus in solid state fermentation. International Journal of Microbiology. 2012;Article ID 683193 .

36. Bibi Z, Ansari A, Zohra RR, Aman A, Qadar ASU. Production of xylan degrading endo-1, 4-b-xylanase from thermophilic Geobascillus stearothermophilus KIBGE-IB29. Journal of Radiation Research and Applied Sciences. 2014;7:478-485.

37. Chakdar H, Kumar M, Pandiyan K, Singh A, Nanjappan K, Kashyap PL, Srivastava AK. 2016. Bacterial xylanases: biology to biotechnology. 3 Biotech. 2016;6:150.

38. Sepahy AA, Ghazi S, Sepahy MA. Cost-effective production and optimization of alkaline xylanase by indigenous Bacillus mojavansis AG137 fermented on agricultural waste. Enzyme Research. 2011;Article ID 593624.

39. Hmidet N, Ali NEH, Haddar A, Kanoun S, Alya SKNM. Alkaline proteases and thermostable a-amylase coproduced by Bacillus licheniformis NH1:Characterization and potential application as detergent additive. Biochemical Engineering Journal. 2009;47:71-79.

40. Vijayaraghavan P, Lazarus S, Vincent SGP. De-hairing protease production by an isolated Bacillus cereus strain AT under solid-state fermentation using cow dung: Biosynthesis and properties. Saudi Journal of Biological Sciences. 2014;21:27-34.

41. Hadder A, Agrebi R, Bougatef A, Hmidet N, SellamiKamoun A, Nasri M. Two detergent stable alkaline serine-proteases from Bacillus mojavensis A21:Purification, characterization and potential application as a laundry detergent additive. Bioresource Technology. 2009;100:3366-3373.

42. Vijayaraghavan P, Vijayan A, Arun A, Jenisha JK, Vincent SGP. Cow dung: a potential biomass substrate for the production of detergent-stable dehairing protease by alkaliphilic Bacillus subtilis strain VV. Springer Plus. 2012;1:76-85.

43. Kim SS, Lee SY, Park KJ, Park SM, An HJ, Hyun JM, Choi YH. Gluconacetobacter sp. gel_SEA623-2, bacterial cellulose producing bacterium isolated from citrus fruit juice. Saudi Journal of Biological Sciences. 2017;24:314-319.

44. Gupta P, Amant K, Sahu A. Isolation of cellulosedegrading bacteria and determination of their cellulolytic potential. International Journal of Microbiology. 2012;Article ID 578925.

45. Sethi S, Batta A, Gupta BL, Gupta S. Optimization of cellulase production from bacteria isolated from soil. ISRN Biotechnology. 2013;Article ID 985685.

46. Gaur R, Tiwari S. Isolation, production, purification and characterization of an organic-solventthermostable alkalophilic cellulase from Bacillus vallismortis RG-07. BMC Biotechnology. 2015;15:1930 . 